CASE REPORT

\title{
X-linked Lissencephaly: a Smooth Brain and a Rough Journey for a 15-Year-Old-Patient
}

Marius-Cristian Zaharia', Diana Anamaria Epure², Ioana Streata ${ }^{3}$, Raluca Ioana Teleanu¹,2

\begin{abstract}
Lissencephaly ("smooth brain") is a malformation of cortical development associated with deficient neuronal migration and abnormal formation of cerebral convolutions or gyri. Although once thought to be rare, malformations of the cerebral cortex are increasingly involved as a major cause of recurrent seizures in children and adults. We described the case of 15-year-old female patient diagnosed with lissencephaly, mental retardation and focal seizures. At 6 months old, the patient developed focal motor seizures. Despite the fact that a CT was performed short after the occurrence of the first seizures, its quality did not allow the identification of cerebral anomalies like subcortical band heterotopia. Genetic testing through multiplex ligation-dependent probe amplification (MLPA) did not reveal any deletion or duplication in genes relevant to the subcortical band heterotopia diagnostic. Thus, in these cases, $\mathrm{MRI}$ assessment represents an useful tool to establish the diagnosis.
\end{abstract}

Keywords: lissencephaly, X-linked, seizures, MRI

\section{Rezumat}

Lisencefalia („creierul neted") este o malformație a dezvoltării corticale asociată cu migrația neuronală deficitară și formarea anormală a circumvoluțiunilor cerebrale sau a girilor. Deși sunt considerate patologii rare, malformațiile cortexului cerebral reprezintă din ce în ce mai frecvent o cauză majoră de producere a crizelor epileptice recurente la copii și adulți. Vă prezentăm cazul unei paciente în vârstă de 15 ani diagnosticată cu lisencefalie, retard mental și crize focale. La 6 luni, pacienta a prezentat crize motorii focale. Deși examenul CT a fost realizat la scurt timp după apariția primelor crize epileptic, calitatea acestei investigații nu a fost suficientă pentru identificarea heterotopiei subcorticale. Testarea genetică prin metoda MLPA nu a identificat nicio deleție sau duplicație în genele relevante pentru diagnosticul de heterotopie subcorticală în bandă. În astfel de cazuri, evaluarea RMN constituie un instrument foarte util în stabilirea diagnosticului.

Cuvinte cheie: lisencefalie, X-linkată, crize epileptice, RMN

\footnotetext{
1 "Carol Davila" University of Medicine and Pharmacy, Bucharest, Romania

${ }^{2}$ Department of Pediatric Neurology, "Dr. Victor Gomoiu” Children's Hospital, Bucharest, Romania

${ }^{3}$ Regional Centre of Medical Genetics Dolj, Emergency County Clinical Hospital, Human Genomics Laboratory, University of Medicine and Pharmacy, Craiova, Romania
}

Corresponding author.

Zaharia Marius, „Carol Davila” University of Medicine and

Pharmacy, Bucharest, Romania.

E-mail: zahariamarius16@gmail.com 


\section{INTRODUCTION}

The cerebral cortex shows a precise layering of multiple neuronal types with distinct form and function, essential for the cognitive functions that define us as humans. Remarkably, cortical neurons are not formed in the cortex itself but in specialized proliferative regions deep in the brain, so that postmitotic neurons must migrate as far as 1000 cell body-lenghts to reach their final destination ${ }^{1}$. Lissencephaly ("smooth brain," LIS) is a malformation of cortical development associated with deficient neuronal migration and abnormal formation of cerebral convolutions or gyri. The LIS spectrum includes agyria, pachygyria, and subcortical band heterotopia ${ }^{2}$. Recently, a gene located on chromosome $\mathrm{X}$ was identified, that causes lissencephaly in carrier women of heterozygous mutations ${ }^{1}$.

The overall incidence of lissencephaly is estimated around 1.2/100,000 births $^{3}$. Although once thought to be rare, malformations of the cerebral cortex represent a major cause of recurrent seizures in children and adults. Magnetic resonance imaging (MRI) has detected focal cortical dysplasia in $25 \%$ of children with intractable focal onset seizures 4 .

This severe developmental disorder leads to a thickened cerebral cortex whose normally folded contour is simplified and smooth. X-linked lissencephaly also known as subcortical band heterotopia is characterized through bilateral bands of disorganized gray matter located just beneath the cortex and separated by a thin band of white matter. The most common clinical manifestation in patients with subcortical band heterotopia is epilepsy with polymorphic seizures ${ }^{5}$. The relative thickness of the band often correlates with the severity of mental retardation and seizures ${ }^{6}$. By far the greatest number of individuals diagnosed are females ${ }^{7}$. The gold standard of diagnosis for this pathology is represented by MRI or anatomopathological examination of the brain.

\section{CLINICAL REPORT}

We report the case of a 15-year-old girl diagnosed with lissencephaly, mental retardation and focal seizures. The patient was born from young, healthy and unrelated parents. Family history revealed that her cousin had Menkes disease. She showed signs of developmental delay since she was 3 months old. The first seizures occurred at 6 months. Computerized tomography, performed immediately after the first seizures, identified a very thin gray matter aspect and ventriculomegaly, es- pecially in the posterior horns (Figure 1). Subsequently, she developed focal motor seizures.

Recent neurological exam showed spastic tetraparesis. She had severe mental retardation (IQ less than 20) and motor stereotypes characterized by hand movements on the median line of the body.

The genetic testing through MLPA showed that there were no deletions or duplications in the genes involved in lissencephaly (PAFAH1B1, DCX, POMT1, POMGnT1 or FLNA). Further genetic investigations need to be done. MRI evaluation detected bilateral bands of heteretopic gray matter located between the ventricular walls and cortex (double cortex aspect) and ventriculomegaly. Those bands were separated from the cortical mantle by a thin layer of white matter (Figure 2 and 3 ).

Based on the evidence previous presented, the diagnostic was clear: heterotopia in the subcortical band, also known as X-linked lissencephaly or double cortex syndrome.

\section{CONCLUSIONS}

$\mathrm{X}$-linked lissencephaly is a rare congenital anomaly of the brain, affecting mostly women, characterized by specific clinical and imagistic signs. Although there are distinctive clinical signs, performing brain MRI is required to establish the diagnosis. Paraclinical investigations are extremely important in order to find the optimal therapeutic scheme, to obtain seizure control and

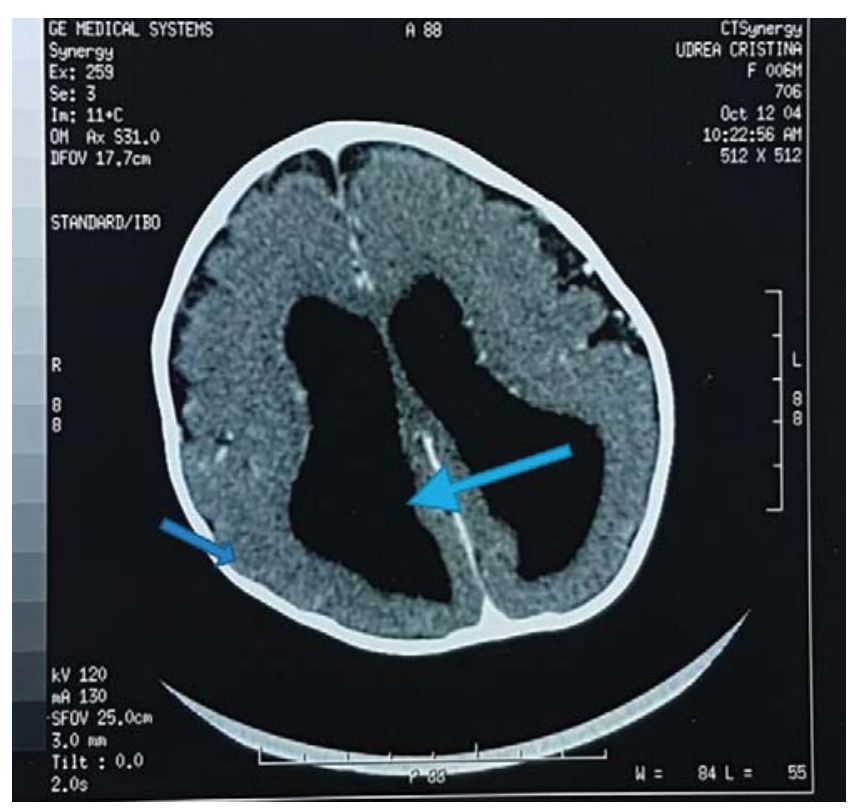

Figure 1. Cerebral CT scan - Lissencephalic aspect: thin gray matter aspect (left arrow) and ventriculomegaly (right arrow). 


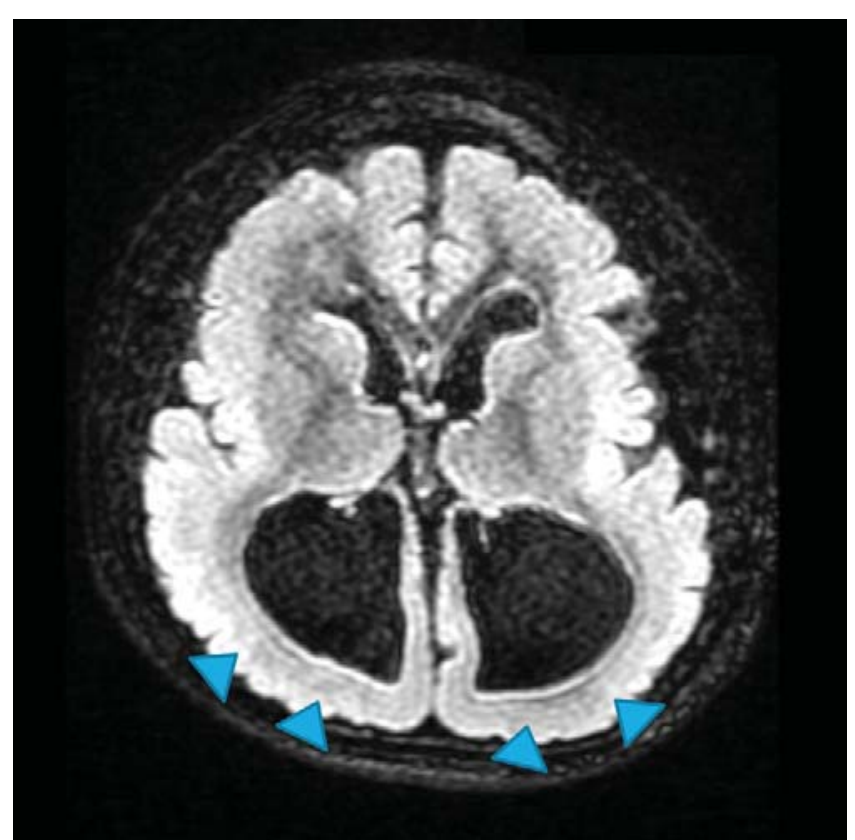

Figure 2. Cerebral MRI T1 Axial View. Ventriculomegaly (arrows).

an efficient long term management, thus increasing quality of life. Despite the fact that a CT was performed right after the first seizures occured, its limitations regarding resolution did not allow the detection of anomalies like subcortical band heterotopia. Also, the importance of the MRI is greater in certain cases such as this one, considering the fact that genetic testing did not detect any alteration in the genes associated with subcortical band heterotopia.

\section{References}

1. Joseph G. Gleeson,1,4,10 Kristina M. Allen,1,10 Jeremy W. Fox, et al. (1998) Doublecortin, a Brain-Specific Gene Mutated in Human X-Linked Lissencephaly and Double Cortex Syndrome, Encodes a Putative Signaling Protein, Cell, Vol. 92, 63-72.

2. Nataliya D.D, Sara C., Ghayda M et al. (2016) Lissencephaly: Expanded imaging and clinical classification, 1-14.

3. Tanaka T, et al. Lis 1 and doublecortin function with dynein to mediate coupling of the nucleus to the centrosome in neuronal migration. J Cell Biol. 2004; 165:709-721.

4. M. Elizabeth Ross, Kristina M. Allen, Anand K. Srivastava et al. (1997) Linkage and physical mapping of X-linked lissencephaly/SBH (XLIS): a gene causing neuronal migration defects

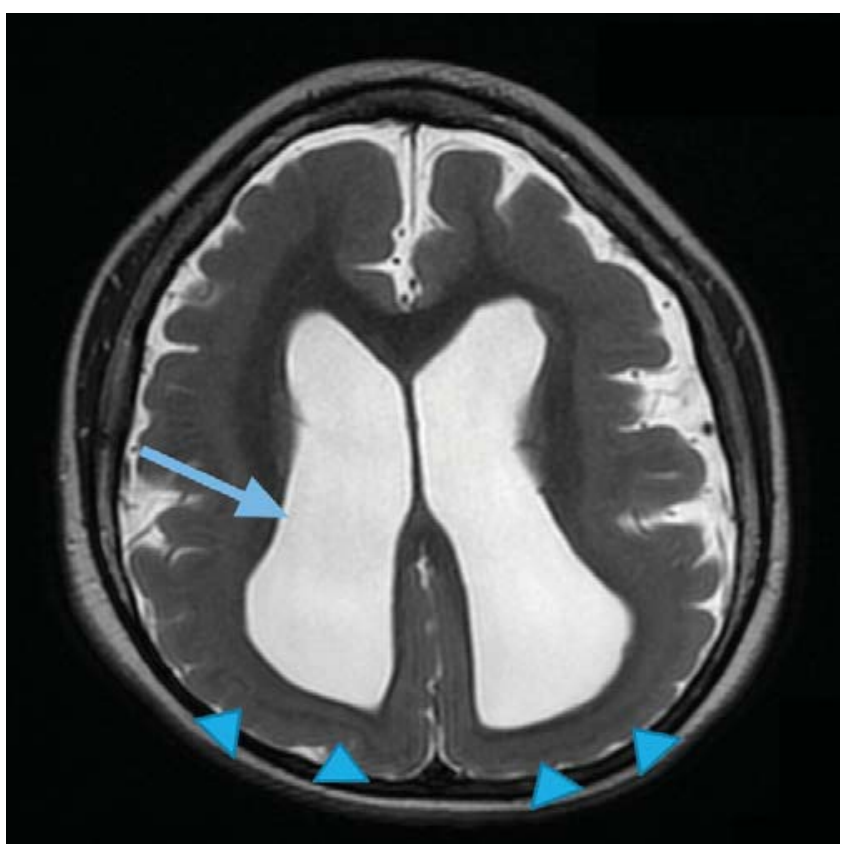

Figure 3. Cerebral MRI T2 Axial View. Ventriculomegaly (arrows). Disorganized gray matter located just beneath the cortex and separated from it by a thin band of white matter (triangles).

\section{Compliance with ethics requirements:}

The authors declare no conflict of interest regarding this article.

The authors declare that all the procedures and experiments of this study respect the ethical standards in the Helsinki Declaration of 1975, as revised in 2008(5), as well as the national law. Informed consent was obtained from all the patients included in the study.

in human brain, Human Molecular Genetics, 1997, Vol. 6, No. 4 555-562.

5. Smaranda Nita, Magdalena Sandu, Raluca Teleanu (2013) Subcortical Band Heterotopia Syndrome In Children - Comparison Of Two Case Reports, Romanian Journal Of Neurology - Volume XII, No. 3, 2013, 152-155.

6. Barkovich, A.J., Guerrini, R., Battaglia, G. et al. (1994) Band hererotopia: correlation of outcome with magnetic resonance imaging parameters. Ann. Neurol., 36, 609-617.

7. Dobyns, W.B., Andermann, E., Anderman, F. et al. (1996) XLinked malformations of neuronal migration. Neurology, 47 , $331-339$. 
